\title{
Biocontrol of the Reniform Nematode by Bacillus firmus GB-126 and Paecilomyces lilacinus 251 on Cotton
}

Juan D. Castillo, Kathy S. Lawrence, and Joseph W. Kloepper, Auburn University Department of Entomology and Plant Pathology, Auburn, AL 36849 \begin{abstract}
nus 251 on cotton. Plant Dis. 97:967-976.
Due to increased restrictions on the use of chemical nematicides, alternative nematode management strategies, including biocontrol, are needed. The objectives of this study were to evaluate the potential of Bacillus firmus GB-126 and Paecilomyces lilacinus 251 in commercial formulations applied separately or concomitantly to manage Rotylenchulus reniformis in cotton grown under greenhouse, microplot, and field conditions. In the greenhouse, seed treated with B. firmus $(1.4 \times$ $\left.10^{7} \mathrm{CFU} / \mathrm{seed}\right)$, an application of P. lilacinus $(0.3 \% \mathrm{vol} / \mathrm{vol}$ of water), or the combination of $B$. firmus and P. lilacinus reduced the number of females, eggs, and vermiforms of $R$. reniformis $(P \leq 0.02)$ and increased populations of free-living nematodes $(P \leq 0.01)$. In microplots
\end{abstract}

Abstract

Castillo, J. D., Lawrence, K. S., and Kloepper, J. W. 2013. Biocontrol of the reniform nematode by Bacillus firmus GB-126 and Paecilomyces lilaci-

and field conditions, populations of $R$. reniformis vermiforms decreased when exposed to $B$. firmus and $P$. lilacinus biocontrol agents at midseason $(P \leq 0.04)$. Furthermore, stem diameter and free-living nematode numbers increased $(P \leq 0.01)$ with the combination of $B$. firmus and $P$. lilacinus. In the field, numbers of females, eggs, and vermiform life stages at the end of the growing season decreased in the presence of the biocontrol agents applied individually or concomitantly $(P \leq 0.01)$. Cotton yields from the application of B. firmus GB-126 and $P$. lilacinus 251 were similar to those from aldicarb, the chemical nematicide standard.
Rotylenchulus reniformis (Linford \& Oliveira), the reniform nematode, is the primary economic pathogen in cotton production in the southeastern region of the United States $(40,41)$. This plantparasitic nematode causes an annual average loss of 5\% of the total cotton production in Louisiana, Mississippi, and Alabama (5). Current management is based on crop rotation and use of chemical nematicides. The Environmental Protection Agency has restricted the use of aldicarb, which is the most common nematicide used in cotton production. The aldicarb application rate for cotton is restricted to $7.8 \mathrm{~kg} / \mathrm{ha}$ ( $7 \mathrm{lb} . / \mathrm{acre}$ ), and aldicarb will be removed from the market by 31 August 2018 (2). Therefore, there is a critical need to explore nematode management alternatives such as biocontrol options.

Over the past 20 years, studies on biological control of $R$. reniformis have reported antagonistic activity of nematophagous fungi and strains of bacteria against different life-cycle stages of nematode (22,48-50). Paecilomyces lilacinus, Pochonia chlamydospora, and an unidentified fungus named Arkansas Fungus have been documented as parasites of the egg stage of $R$. reniformis $(28,49)$. The vermiform life stages were reported to be colonized by the fungi Arthrographis spp., Pseudorobillarda spp., and Fusarium equiseti (33). The zoosporic fungus Catenaria auxiliaris was reported colonizing $R$. reniformis vermiform life stages (8). Furthermore, strains of the bacteria Pasteuria spp. and Pseudomonas fluorescens have been reported to reduce the number of $R$. reniformis in soil $(17,22,43)$. Recently, soils suppressive to $R$. reniformis have been reported in Louisiana and Texas; however, the agents responsible for this suppression have not been identified (42).

Currently, there are two biocontrol agents available for nematode control on cotton (Gossypium hirsutum, Linnaeus): Paecilomyces lilacinus strain 251 and Bacillus firmus strain GB-

Corresponding author: K. S. Lawrence, E-mail: lawrekk@auburn.edu

Accepted for publication 24 January 2013.

http://dx.doi.org/10.1094/PDIS-10-12-0978-RE

(C) 2013 The American Phytopathological Society
126. P. lilacinus strain 251 is an egg-parasite fungus that was reported to reduce egg numbers of Meloidogyne javanica $(14,27)$ and $R$. reniformis on tomato (48). It is currently commercialized in a wettable powder formulation under the name of NemOut. $B$. firmus strain GB-126 is a bacterium originally isolated in Israel and currently formulated as a seed treatment under the name VOTiVO or as a wettable powder under the name Nortica 5\%WP.

$P$. lilacinus was initially isolated from eggs of $M$. incognita in Peru (21) and later reported colonizing Meloidogyne spp. and Heterodera spp. in other parts of the world $(11,26,45)$. Its pathogenicity varies depending on the isolates. The mechanism of infection is by penetration of the nematode egg shell by an appressorium that develops from hyphae and secretes PL protease $(6,32)$. Additionally, the production of chitinase enzymes and acetic acid has also been reported to be involved in the mode of action (25). A group of toxins called the leucinotoxins was reported to be responsible for the biocontrol activity of isolates of $P$. lilacinus from Australia (38).

Walters and Barker (48) found that $P$. lilacinus reduced populations of $R$. reniformis nematodes $36 \%$ under greenhouse conditions and $59 \%$ in microplot trials on tomato, when the fungus was applied via infested rice grains. Further, an isolate of $P$. lilacinus from eggs of $R$. reniformis was reported in cotton plants (10). The isolate reduced the number of $R$. reniformis eggs under greenhouse conditions when the fungus was applied at planting using wheat or oat seed as carriers (9). P. lilacinus has been observed growing intercellularly in the epidermis of tomato roots (7), and, under in vitro conditions, it parasitizes eggs within $48 \mathrm{~h}(9)$.

$B$. firmus strain GB-126 in a field environment reduced $M$. incognita in tomato roots with a single application (47). Furthermore, it reduced populations of Radopholus similis, Ditylenchus dipsaci, and Heterodera glycines under in vitro conditions $(34,44,47)$. In vitro studies suggest that the mode of action may be bioactive secondary compounds that inhibit egg development and root infection of $M$. incognita $(34,47)$.

The objective of this study was to evaluate the commercial biocontrol products $B$. firmus GB-126 and P. lilacinus 251 when applied separately or in combination to determine their potential to reduce $R$. reniformis populations and enhance cotton plant growth under greenhouse, microplot, and field production systems. Tests 
were conducted with each biological agent to assess its capacity to reduce nematode populations in soil, the optimum rate of application, and the effectiveness of combined applications of multiple biological agents.

\section{Materials and Methods}

Plant material, nematode inoculum, and soil. To evaluate the response of Rotylenchulus reniformis to applications of $B$. firmus (Bayer Crop Science) and P. lilacinus (Plato Industries Ltd.) on
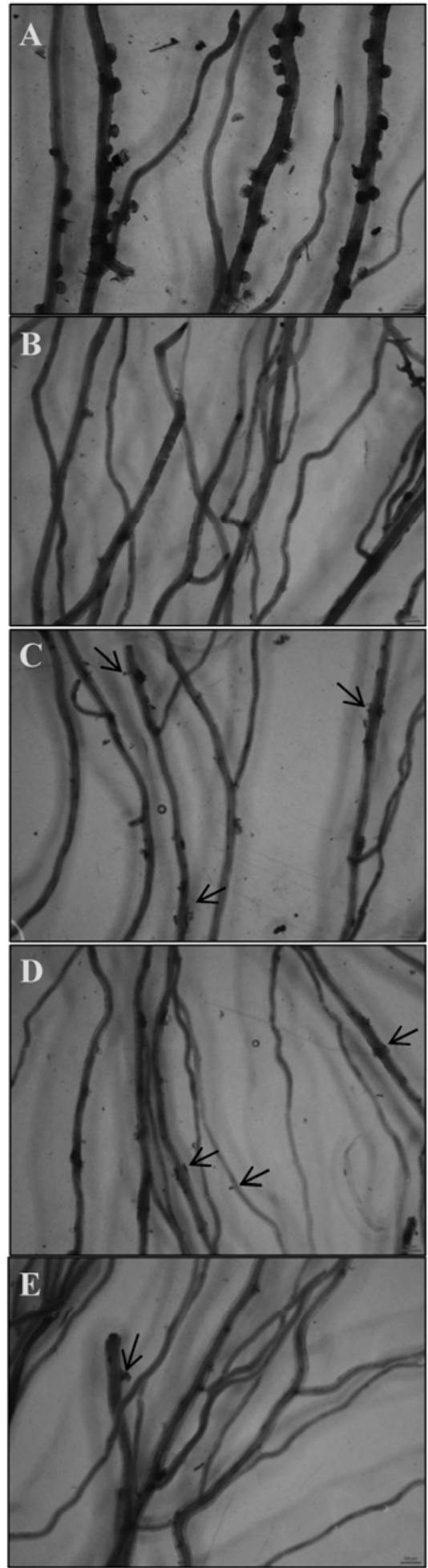

Fig. 1. Rotylenchulus reniformis females feeding from the cotton roots treated with Paecilomyces lilacinus strain 251 at 30 days after planting. A, Untreated control; B, Aldicarb (5.6 kg/ha); C, Paecilomyces lilacinus ( $0.1 \%$ vol $/ \mathrm{vol})$; D, P. lilacinus $(0.2 \%$ $\mathrm{vol} / \mathrm{vol})$; and $\mathrm{E}$, P. lilacinus ( $0.3 \% \mathrm{vol} / \mathrm{vol})$. cotton, rate, competition, and combination trials were conducted in the Plant Science Research Center greenhouses at Auburn University. In all the experiments, the cotton cultivar grown was 'Stoneville 5458B2RF'. Cotton seed were treated with the $B$. firmus bacterium provided by Bayer Crop Science. The presence of viable $B$. firmus bacteria on the seed was confirmed by culturing the treated seed on tryptic soy agar, $\mathrm{pH}$ 8.0.

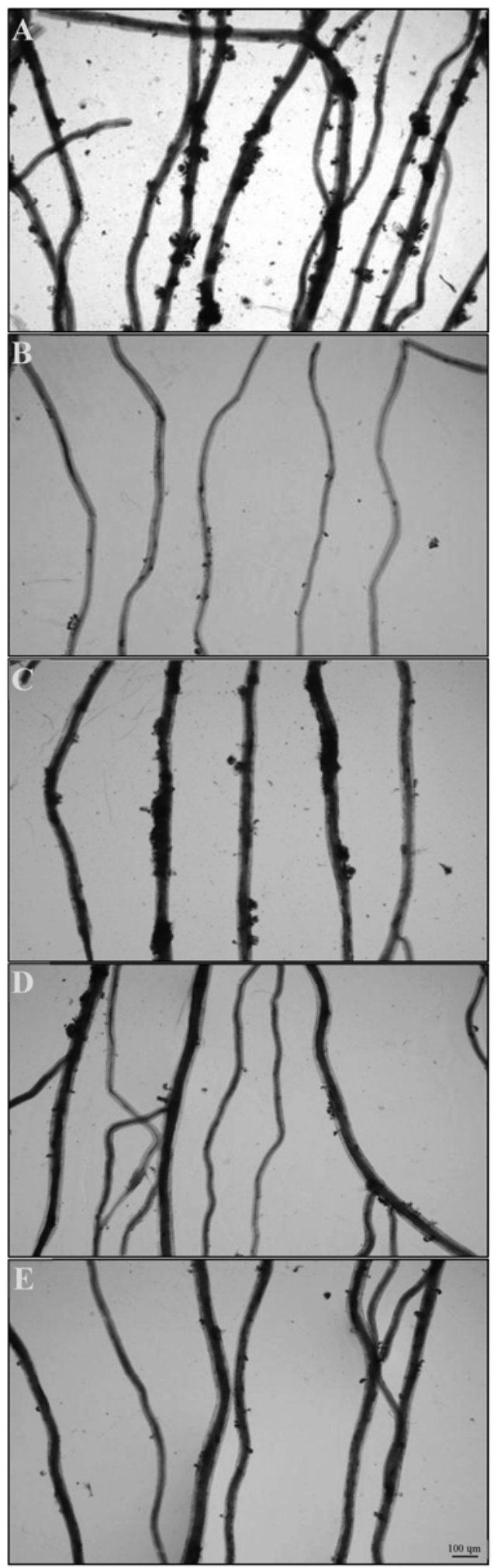

Fig. 2. Rotylenchulus reniformis females feeding from the cotton roots treated with Bacillus firmus strain GB-126 at 30 days after planting. A, Untreated control; B, Aldicarb (5.6 kg/ha); C, Bacillus firmus $\left(1 \times 10^{6} \mathrm{CFU} /\right.$ seed $) ; \mathrm{D}$, B. firmus $\left(7 \times 10^{6}\right.$ $\mathrm{CFU} /$ seed); and $\mathbf{E}$, B. firmus (1.4 × $10^{7} \mathrm{CFU} /$ seed $)$. 
Nematode inoculum of $R$. reniformis for all tests was supplied by increasing stock cultures in the greenhouse. The vermiform life stages of $R$. reniformis were extracted from the soil by modified gravity sieving followed by sucrose centrifugation-flotation (23). To maximize the efficiency of extraction, eggs were also extracted from the cotton roots by shaking the root system in a $1 \% \mathrm{NaOCl}$ solution for $4 \mathrm{~min}$ at $120 \mathrm{rpm}$. The nematode egg suspension was collected and rinsed with water through a $25-\mu \mathrm{m}$ sieve (20). Eggs were placed in a Baerman dish for $24 \mathrm{~h}$, and hatched second-stage juveniles were enumerated at $\times 40$ magnification with an inverted TS100 Nikon microscope and standardized to 2,000 vermiform life stages per $500 \mathrm{~cm}^{3}$ of soil. Nematodes were added to all pots by pipetting $2 \mathrm{ml}$ of the nematode suspension into 2-cm-deep wells in each pot and covering the depressions to eliminate desiccation of the nematodes.

The soil used in all tests was a Decatur silty clay loam (sand-siltclay, 17.5-51.3-31.2\%; nitrogen, 0.16\%; organic matter, 2.2; $\mathrm{pH}$ 7.24) from the Tennessee Valley Research and Extension Center (TVREC) near Belle Mina, AL. The soil was autoclaved in the competition tests using two 90 -min cycles at $130^{\circ} \mathrm{C}$ at $1.0 \mathrm{~kg} / \mathrm{cm}^{3}$ pressure with a 24-h cool down between cycles to remove any natural competition for the microflora.

Greenhouse trials rate evaluations. In the first set of trials were rate optimization tests, where each biocontrol agent was evaluated individually in autoclaved field soil at three different rates. Rates included those recommended by the manufacturers and a lower and higher rate. In the initial trial with P. lilacinus, treatments consisted of (i) control without $R$. reniformis, (ii) control with $R$. reniformis, (iii) P. lilacinus $(0.02 \% \mathrm{vol} / \mathrm{vol})$, (iv) P. lilaci$n u s(0.1 \% \mathrm{vol} / \mathrm{vol})$, and (v) P. lilacinus $(0.2 \% \mathrm{vol} / \mathrm{vol})$. In the initial trial with $B$. firmus, treatments were (i) untreated seed with $R$. reniformis; (ii) imidacloprid (500 g a.i. per $100 \mathrm{~kg}$ of seed), a standard insecticide; (iii) B. firmus $\left(7 \times 10^{4} \mathrm{CFU} / \mathrm{seed}\right)$ plus imidacloprid (500 g a.i. per $100 \mathrm{~kg}$ of seed); (iv) B. firmus $\left(7 \times 10^{5}\right.$ CFU/seed) plus imidacloprid (500 g a.i. per $100 \mathrm{~kg}$ of seed); and (v) B. firmus $\left(7 \times 10^{6} \mathrm{CFU} / \mathrm{seed}\right)$ plus imidacloprid (500 $\mathrm{g}$ a.i. per $100 \mathrm{~kg}$ of seed). The standard insecticide seed treatment imidacloprid was included because this insecticide is commonly applied as a combination seed treatment and was tested to determine its effect on B. firmus and R. reniformis. The seeds for each treatment were planted into the autoclaved soil in $500-\mathrm{cm}^{3}$ polystyrene pots, and the nematode inoculum was immediately added. Pots were arranged on the greenhouse bench in a randomized complete block design (RCBD) with five replications and a total of 300 experi- mental units in the $P$. lilacinus and $B$. firmus trials. Greenhouse temperatures were 24 to $35^{\circ} \mathrm{C}$, averaging $29^{\circ} \mathrm{C}$ throughout the tests. Soil moisture was kept between 40 and $60 \%$ of the maximum water-holding capacity. Destructive harvesting occurred every 5 days for 30 days for a total of six harvest times throughout the duration of the test. Variables measured at each harvest included plant height, shoot and root weights, $R$. reniformis females and eggs per gram of root, and the number of $R$. reniformis vermiform life stages in $500 \mathrm{~cm}^{3}$ of soil. The numbers of vermiform life stages in $500 \mathrm{~cm}^{3}$ of soil and numbers of eggs per gram of root were extracted as previously described. Roots were stained with acid fuchsin to facilitate counting the females in the root at $\times 5$ using a Nikon SMZ800 compound microscope (18). The P. lilacinus and $B$. firmus trials were immediately repeated after the 30-day harvest of the first trial.

Greenhouse microflora competition evaluation. In the competition trials, rates of $B$. firmus and P. lilacinus that reduced nematode numbers in the first set of rate optimization trials were selected with additional rates for evaluation in nonautoclaved field soil, which allowed for natural microflora competition. Treatments in the natural competition trial with P. lilacinus were applied at planting and consisted of (i) untreated control, (ii) aldicarb (Temik $15 \mathrm{G}$ applied at $5.6 \mathrm{~kg} / \mathrm{ha}$ ), (iii) $P$. lilacinus $(0.1 \% \mathrm{vol} / \mathrm{vol})$, (iv) $P$. lilacinus $(0.2 \% \mathrm{vol} / \mathrm{vol})$, and (v) P. lilacinus $(0.3 \% \mathrm{vol} / \mathrm{vol})$. In the natural competition trial with $B$. firmus, treatments included (i) untreated control, (ii) aldicarb (5.6 kg/ha), (iii) B. firmus $\left(1 \times 10^{6}\right.$ $\mathrm{CFU} / \mathrm{seed})$, (iv) B. firmus $\left(7 \times 10^{6} \mathrm{CFU} / \mathrm{seed}\right)$, and (v) B. firmus $\left(1.4 \times 10^{7} \mathrm{CFU} / \mathrm{seed}\right)$. In both trials, the $B$. firmus and $P$. lilacinus rates were compared with an untreated seed control and aldicarb. The treatments were planted into $500-\mathrm{cm}^{3}$ polystyrene pots containing the silt loam field soil, and the nematode inoculum was immediately added. These tests were placed in an RCBD with five replications for a total of 300 experimental units in the $P$. lilacinus and $B$. firmus trials. Variables measured were the same as in the rate-optimization trials. Plant parameters and nematode populations were monitored as previously described. In addition, root length, surface area, and number of tips were determined using WinRHIZO Pro (Regent Instruments Inc.). The test was immediately repeated after the 30-day harvest of the first trial for a total of two trials.

Greenhouse combination evaluations. In the combination trials, each biocontrol agent (B. firmus and P. lilacinus) was evaluated separately and concomitantly. This set of trials adding the $B$. firmus and $P$. lilacinus concomitant treatment used the optimum rate of

Table 1. Effect of Paecilomyces lilacinus strain 251 on nematodes in roots at 30 days after planting under greenhouse conditions in nonautoclaved field soil $(P \leq 0.05)$

\begin{tabular}{|c|c|c|c|c|c|c|}
\hline \multirow[b]{3}{*}{ Treatments } & \multicolumn{6}{|c|}{ Rotylenchulus reniformis per gram of root } \\
\hline & \multirow[b]{2}{*}{ Females } & \multicolumn{2}{|c|}{ Dunnett's $P$ vs. } & \multirow[b]{2}{*}{ Eggs } & \multicolumn{2}{|c|}{ Dunnett's $P$ vs. } \\
\hline & & Control & Aldicarb & & Control & Aldicarb \\
\hline Control & 484 & & & 3,668 & & \\
\hline Aldicarb & 105 & 0.001 & & 547 & 0.001 & \\
\hline P. lilacinus $(0.1 \% \mathrm{vol} / \mathrm{vol})$ & 248 & 0.001 & 0.001 & 1,841 & 0.066 & 0.003 \\
\hline P. lilacinus $(0.2 \% \mathrm{vol} / \mathrm{vol})$ & 266 & 0.001 & 0.001 & 2,264 & 0.637 & 0.361 \\
\hline P. lilacinus $(0.3 \% \mathrm{vol} / \mathrm{vol})$ & 255 & 0.001 & 0.001 & 1,767 & 0.030 & 0.002 \\
\hline
\end{tabular}

Table 2. Effect of Paecilomyces lilacinus strain 251 on nematodes in soil at 30 days after planting under greenhouse conditions in nonautoclaved field soil ( $P$ $\leq 0.05)$

\begin{tabular}{|c|c|c|c|c|c|c|}
\hline \multirow[b]{3}{*}{ Treatments } & \multicolumn{6}{|c|}{ Nematodes per $500 \mathrm{~cm}^{3}$ of soil } \\
\hline & \multirow[b]{2}{*}{ Vermiforms } & \multicolumn{2}{|c|}{ Dunnett's $P$ vs. } & \multirow[b]{2}{*}{ Free-living } & \multicolumn{2}{|c|}{ Dunnett's $P$ vs. } \\
\hline & & Control & Aldicarb & & Control & Aldicarb \\
\hline Control & 1,771 & & $\ldots$ & 459 & & $\ldots$ \\
\hline Aldicarb & 302 & 0.001 & $\ldots$ & 70 & 0.001 & \\
\hline P. lilacinus $(0.1 \% \mathrm{vol} / \mathrm{vol})$ & 945 & 0.019 & 0.001 & 518 & 0.891 & 0.001 \\
\hline P. lilacinus $(0.2 \% \mathrm{vol} / \mathrm{vol})$ & 1,177 & 0.171 & 0.001 & 751 & 0.593 & 0.001 \\
\hline P. lilacinus $(0.3 \% \mathrm{vol} / \mathrm{vol})$ & 993 & 0.005 & 0.001 & 1,685 & 0.003 & 0.001 \\
\hline
\end{tabular}


each biocontrol agent as determined in the first greenhouse trials and then confirmed in the natural competition trials. Treatments included (i) untreated control, (ii) aldicarb $(5.6 \mathrm{~kg} / \mathrm{ha}$ ), (iii) $B$. firmus $\left(1.4 \times 10^{7} \mathrm{CFU} / \mathrm{seed}\right)$, (iv) P. lilacinus $(0.3 \% \mathrm{vol} / \mathrm{vol})(1.5 \mathrm{~g}$ per $100 \mathrm{ml})$, and (v) B. firmus $\left(1.4 \times 10^{7} \mathrm{CFU} / \mathrm{seed}\right)$ plus $P$. lilacinus $(0.3 \% \mathrm{vol} / \mathrm{vol})$. Parameters measured were the same as in the rate-optimization and natural-competition trials. The combination trial was arranged in an RCBD design with five replications and was repeated twice. Plant height, shoot weight, and root architecture (root length, surface area, and number of tips) were recorded at 15 and 30 DAP (days after planting). Numbers of females and eggs per gram of root were determined at the same time periods.

Microplot evaluations. The optimum rate and combination treatments were also tested in microplots after being tested in the controlled greenhouse environment and before testing in variable field site. The microplots were $4,500-\mathrm{cm}^{3}$ plastic tree containers filled with $12.5 \mathrm{~kg}$ of the same Decatur silty clay loam field soil described previously. The treatments included the following: (i) untreated control, (ii) aldicarb $(5.6 \mathrm{~kg} / \mathrm{ha})$, (iii) B. firmus $\left(1.4 \times 10^{7}\right.$ CFU/seed), (iv) P. lilacinus ( $0.3 \% \mathrm{vol} / \mathrm{vol})$, and (v) B. firmus $(1.4 \times$ $\left.10^{7} \mathrm{CFU} / \mathrm{seed}\right)$ and $P$. lilacinus $(0.3 \% \mathrm{vol} / \mathrm{vol})$. The microplot trial was planted with four treated cotton seeds, creating a $30-\mathrm{cm}$ length row. In addition to the B. firmus seed treatment, a 5\% wettable powder formulation of $B$. firmus (Nortica) and the P. lilacinus was applied as a soil drench at 7 days preplanting and 7 days postplanting. This wettable powder formulation contained $3 \times 10^{9}$ spores per gram of product. Microplot treatments were placed in an RCBD with five replications, and the entire test was repeated in a separate area of the microplot field in 2011. An extra microplot was connected to a temperature and moisture data logger to record these environmental variables during the growing season. Average soil temperature during the whole trial was $26.8^{\circ} \mathrm{C}$ and volume water content of $0.2 \% \mathrm{vol} / \mathrm{vol}$ (field capacity). Plant parameters recorded included plant height, stem diameter, number of nodes, and yield. Nematode populations were monitored by determining numbers of females and eggs per gram of root and number of vermiform life stages and free-living nematodes per $150 \mathrm{~cm}^{3}$ of soil. All parameters were recorded at 30,60, 90, and 150 DAP.

Field evaluations. Field trials were conducted at the TVREC in a field infested with $R$. reniformis. The soil in this field is a Decatur silty clay loam. The treatments were the same as the microplot trial, with the $B$. firmus and $P$. lilacinus biological treatments applied 7 days preplanting, at planting, and 7 days postplanting.
Each experimental unit consisted of a two-row plot (7.6 by $2 \mathrm{~m}$ ) planted with 100 cotton seeds per row. The field trials were arranged as an RCBD with five replications, and the entire test was repeated. For each plot, the biocontrol treatment was suspended in 4 liters of water and applied to each row using a garden sprinkler can. The same amount of water was applied to the control and aldicarb treatments. A data logger was installed within the field to record moisture and temperature during the growing season. Soil moisture was at field capacity, with an average volume of water content of $0.27 \mathrm{~m}^{3} / \mathrm{m}^{3}$. The field was irrigated as needed with a linear overhead sprinkler irrigation system.

Three plants in each plot were marked to allow plant variables to be determined from the same plants during the entire growing season. Variables recorded were plant height, stem diameter, and number of nodes. Nematode variables included numbers of females and eggs per gram of root and numbers of vermiform life stages and free-living nematodes in soil. Data were collected at 0,30,60, 90 , and 150 DAP. At the end of the growing season, cotton yield was collected with a Case IH plot picker.

Data analysis. Data collected in all the trials were analyzed in SAS 9.1 (SAS Institute Inc.) using the PROC GLIMMIX procedure. Model statements included the biological treatments fixed effects, and the random effects included time and replications. The normal distributional assumption was evaluated with the student panel graphs. Nematode data, including nematode populations of vermiform life stages, eggs, and females per gram of root, were transformed to log-normal to satisfy the normality assumption. Least squares means estimates from the analyses using a log-normal distribution function were back-transformed to the original scale and then presented. Dunnett's option was used in the LSMEANS statement to assess the differences between treatments, the untreated control, and aldicarb. Dunnett's $P$ values are presented in the tables.

\section{Results}

Greenhouse evaluations. In the biological-rate trials with autoclaved soil, the highest rate of P. lilacinus $(0.2 \% \mathrm{vol} / \mathrm{vol})$ reduced the number of $R$. reniformis females and number of eggs per gram of root between 15 and 25 DAP (Fig. 1). The same treatment also increased the root fresh weight of the cotton plants when compared with the untreated control $(P \leq 0.01)$ (data not shown). Based on these results, the rate $0.2 \%$ ( $\mathrm{vol} / \mathrm{vol}$ ) was selected to be evaluated in the field-soil trial in a second greenhouse trial.

Table 3. Effect of Paecilomyces lilacinus strain 251 on plant variables at 30 days after planting under greenhouse conditions in nonautoclaved field soil $(P \leq$ $0.05)^{\mathrm{a}}$

\begin{tabular}{|c|c|c|c|c|c|c|c|c|c|}
\hline \multirow[b]{2}{*}{ Treatments } & \multirow[b]{2}{*}{ H (cm) } & \multicolumn{2}{|c|}{ Dunnett's $P$ vs. } & \multirow[b]{2}{*}{ ShDW (g) } & \multicolumn{2}{|c|}{ Dunnett's $P$ vs. } & \multirow[b]{2}{*}{ RFW (g) } & \multicolumn{2}{|c|}{ Dunnett's $P$ vs. } \\
\hline & & Control & Aldicarb & & Control & Aldicarb & & Control & Aldicarb \\
\hline Control & 13.6 & & $\ldots$ & 0.8 & & $\ldots$ & 3.1 & & $\ldots$ \\
\hline Aldicarb & 13.9 & 0.764 & $\ldots$ & 0.8 & 0.976 & $\ldots$ & 3.6 & 0.226 & $\ldots$ \\
\hline \multicolumn{10}{|l|}{ P. lilacinus } \\
\hline $0.1 \%(\mathrm{vol} / \mathrm{vol})$ & 14.3 & 0.605 & 0.704 & 0.8 & 0.805 & 0.711 & 3.6 & 0.343 & 0.772 \\
\hline $0.2 \%(\mathrm{vol} / \mathrm{vol})$ & 16.0 & 0.121 & 0.103 & 0.9 & 0.397 & 0.324 & 3.8 & 0.273 & 0.909 \\
\hline $0.3 \%(\mathrm{vol} / \mathrm{vol})$ & 17.0 & 0.012 & 0.003 & 1.1 & 0.003 & 0.001 & 4.7 & 0.026 & 0.021 \\
\hline
\end{tabular}

${ }^{\mathrm{a}} \mathrm{H}=$ height, ShDW = shoot dry weight, and RFW = root fresh weight.

Table 4. Effect of Paecilomyces lilacinus strain 251 on root architecture at 30 days after planting under greenhouse conditions in nonautoclaved field soil ( $P$ $\leq 0.05)^{\mathrm{a}}$

\begin{tabular}{|c|c|c|c|c|c|c|c|c|c|}
\hline \multirow[b]{2}{*}{ Treatments } & \multirow[b]{2}{*}{$\mathbf{L}(\mathbf{c m})$} & \multicolumn{2}{|c|}{ Dunnett's $P$ vs. } & \multirow[b]{2}{*}{$\mathrm{SA}\left(\mathrm{cm}^{3}\right)$} & \multicolumn{2}{|c|}{ Dunnett's $P$ vs. } & \multirow[b]{2}{*}{ Tips } & \multicolumn{2}{|c|}{ Dunnett's $P$ vs. } \\
\hline & & Control & Aldicarb & & Control & Aldicarb & & Control & Aldicarb \\
\hline Control & 354 & $\ldots$ & $\ldots$ & 171 & $\ldots$ & $\ldots$ & 469 & $\ldots$ & $\ldots$ \\
\hline Aldicarb & 380 & 0.657 & $\ldots$ & 167 & 0.764 & $\ldots$ & 474 & 0.872 & $\ldots$ \\
\hline P. lilacinus & & & & & & & & & \\
\hline $0.1 \%(\mathrm{vol} / \mathrm{vol})$ & 391 & 0.419 & 0.694 & 179 & 0.605 & 0.704 & 432 & 0.745 & 0.530 \\
\hline $0.2 \%(\mathrm{vol} / \mathrm{vol})$ & 411 & 0.309 & 0.497 & 178 & 0.121 & 0.103 & 542 & 0.295 & 0.272 \\
\hline $0.3 \%(\mathrm{vol} / \mathrm{vol})$ & 437 & 0.226 & 0.348 & 225 & 0.012 & 0.003 & 550 & 0.304 & 0.294 \\
\hline
\end{tabular}

${ }^{\mathrm{a}} \mathrm{L}=$ length, $\mathrm{SA}=$ superficial area, and Tips = number of tips. 
In the $B$. firmus trial in autoclaved soil, the highest $B$. firmus seed treatment rate $\left(7 \times 10^{6} \mathrm{CFU} / \mathrm{seed}\right)$ reduced the number of $R$. reniformis females and vermiform life stages in the soil between 20 and 30 DAP compared with the control $(P \leq 0.01)$ (data not shown) (Fig. 2). Furthermore, the insecticide imidacloprid seed treatment control did not influence any plant growth parameters or reduce populations of $R$. reniformis $(P \leq 0.77)$. Hence, this rate (7 $\left.\times 10^{6} \mathrm{CFU} / \mathrm{seed}\right)$ and the $1.4 \times 10^{7} \mathrm{CFU} /$ seed rate were selected to be evaluated in the field-soil trial in a second greenhouse trial. Also, imidacloprid seed treatment was used in all the following trials due to its inherent effect on $R$. reniformis.

In the natural microflora competition trial in nonautoclaved field soil, $P$. lilacinus at the highest rate $(0.3 \% \mathrm{vol} / \mathrm{vol})$ reduced the number of females $(P \leq 0.001)$ and eggs $(P \leq 0.031)$ in the root and vermiform life stages in the soil $(P \leq 0.005)$ (Tables 1 and 2$)$. Vermiform life stages in the soil were also reduced by the lower
$(0.1 \% \mathrm{vol} / \mathrm{vol})$ rates of $P$. lilacinus at 20 to $30 \mathrm{DAP}(P \leq 0.003)$ (Tables 1 and 2 ). The higher rate increased the number of freeliving nematodes $(P \leq 0.001)$ as well. Plant height and shoot dry weight $(P \leq 0.01)$ were also greater at the higher rate of $P$. lilacinus as well as root fresh weight and root surface area at 30 DAP $(P \leq$ $0.026)$. The medium $(0.1 \% \mathrm{vol} / \mathrm{vol})$ and lower $(0.01 \% \mathrm{vol} / \mathrm{vol})$ rates of $P$. lilacinus and aldicarb did not influence root variables as compared with the untreated control $(P \leq 0.273)$ (Tables 3 and 4).

$B$. firmus at the highest rate $\left(1.4 \times 10^{7} \mathrm{CFU} /\right.$ seed $)$ supported a lower number of $R$. reniformis females and eggs per gram of root compared with the untreated control at $30 \mathrm{DAP}(P \leq 0.036)$ (Tables 5 and 6). At the medium and high rates of B. firmus, vermiform life stages in the soil were reduced compared with the untreated control $(P \leq 0.009)$ (Fig. 2) and similar to the aldicarb treatment at 30 DAP (Tables 5 and 6). There were no differences between the number of free-living nematodes with the $B$. firmus rates and the untreated

Table 5. Effect of Bacillus firmus strain GB-126 on nematodes in roots at 30 days after planting under greenhouse conditions in nonautoclaved field soil $(P \leq$ $0.05)$

\begin{tabular}{|c|c|c|c|c|c|c|}
\hline \multirow[b]{3}{*}{ Treatments } & \multicolumn{6}{|c|}{ Rotylenchulus reniformis per gram of root } \\
\hline & \multirow[b]{2}{*}{ Females } & \multicolumn{2}{|c|}{ Dunnett's $P$ vs. } & \multirow[b]{2}{*}{ Eggs } & \multicolumn{2}{|c|}{ Dunnett's $P$ vs. } \\
\hline & & Control & Aldicarb & & Control & Aldicarb \\
\hline Control & 650 & & $\ldots$ & 2121 & & $\ldots$ \\
\hline Aldicarb & 260 & 0.001 & $\ldots$ & 1326 & 0.021 & $\ldots$ \\
\hline \multicolumn{7}{|l|}{ B. firmus } \\
\hline $1 \times 10^{6} \mathrm{CFU} / \mathrm{seed}$ & 497 & 0.131 & 0.008 & 1910 & 0.507 & 0.060 \\
\hline $7 \times 10^{6} \mathrm{CFU} /$ seed & 477 & 0.071 & 0.001 & 1636 & 0.116 & 0.237 \\
\hline $1.4 \times 10^{7} \mathrm{CFU} / \mathrm{seed}$ & 448 & 0.036 & 0.022 & 1684 & 0.001 & 0.512 \\
\hline
\end{tabular}

Table 6. Effect of Bacillus firmus strain GB-126 on nematodes in soil at 30 days after planting under greenhouse conditions in nonautoclaved field soil ( $P \leq$ $0.05)$

\begin{tabular}{|c|c|c|c|c|c|c|}
\hline \multirow[b]{3}{*}{ Treatments } & \multicolumn{6}{|c|}{ Nematodes per $500 \mathrm{~cm}^{3}$ of soil } \\
\hline & \multirow[b]{2}{*}{ Vermiforms } & \multicolumn{2}{|c|}{ Dunnett's $\boldsymbol{P}$ vs. } & \multirow[b]{2}{*}{ Free-living } & \multicolumn{2}{|c|}{ Dunnett's $P$ vs. } \\
\hline & & Control & Aldicarb & & Control & Aldicarb \\
\hline Control & 1,731 & $\ldots$ & $\ldots$ & 316 & $\ldots$ & $\ldots$ \\
\hline Aldicarb & 725 & 0.001 & $\ldots$ & 262 & 0.548 & $\ldots$ \\
\hline \multicolumn{7}{|l|}{ B. firmus } \\
\hline $1 \times 10^{6} \mathrm{CFU} /$ seed & 1,416 & 0.218 & 0.194 & 474 & 0.519 & 0.301 \\
\hline $7 \times 10^{6} \mathrm{CFU} /$ seed & 1,005 & 0.002 & 0.160 & 324 & 0.981 & 0.539 \\
\hline $1.4 \times 10^{7} \mathrm{CFU} /$ seed & 1,099 & 0.009 & 0.105 & 402 & 0.410 & 0.207 \\
\hline
\end{tabular}

Table 7. Effect of Bacillus firmus strain GB-126 on plant variables 15 and 30 days after planting under greenhouse conditions in nonautoclaved field soil at three different seed treatment rates $(P \leq 0.05)^{\mathrm{a}}$

\begin{tabular}{|c|c|c|c|c|c|c|c|c|c|}
\hline \multirow[b]{2}{*}{ Treatments } & \multirow[b]{2}{*}{$\mathrm{H}(\mathrm{cm})$} & \multicolumn{2}{|c|}{ Dunnett's $P$ vs. } & \multirow[b]{2}{*}{ ShDW (g) } & \multicolumn{2}{|c|}{ Dunnett's $P$ vs. } & \multirow[b]{2}{*}{ RFW (g) } & \multicolumn{2}{|c|}{ Dunnett's $P$ vs. } \\
\hline & & Control & Aldicarb & & Control & Aldicarb & & Control & Aldicarb \\
\hline Control & 10.4 & $\ldots$ & $\ldots$ & 0.6 & $\ldots$ & $\ldots$ & 3.1 & $\ldots$ & $\ldots$ \\
\hline Aldicarb & 10.4 & 1.000 & $\ldots$ & 0.56 & 0.625 & $\ldots$ & 2.3 & 0.002 & $\ldots$ \\
\hline \multicolumn{10}{|l|}{ B. firmus } \\
\hline $1 \times 10^{6} \mathrm{CFU} /$ seed) & 9.8 & 0.849 & 0.843 & 0.56 & 0.673 & 0.965 & 3.3 & 0.629 & 0.009 \\
\hline $7 \times 10^{6} \mathrm{CFU} /$ seed) & 10.4 & 1.000 & 1.000 & 0.53 & 0.319 & 0.569 & 3 & 0.704 & 0.022 \\
\hline $\left.1.4 \times 10^{7} \mathrm{CFU} / \mathrm{seed}\right)$ & 10.6 & 0.987 & 0.989 & 0.6 & 0.968 & 0.472 & 3.6 & 0.148 & 0.000 \\
\hline
\end{tabular}

${ }^{\mathrm{a}} \mathrm{H}=$ height, ShDW = shoot dry weight, and RFW = root fresh weight.

Table 8. Effect of Bacillus firmus strain GB-126 on root architecture 15 and 30 days after planting under greenhouse conditions in nonautoclaved field soil at three different seed treatment rates $(P \leq 0.05)^{\mathrm{a}}$

\begin{tabular}{|c|c|c|c|c|c|c|c|c|c|}
\hline \multirow[b]{2}{*}{ Treatments } & \multirow[b]{2}{*}{$\mathbf{L}(\mathbf{c m})$} & \multicolumn{2}{|c|}{ Dunnett's $P$ vs. } & \multirow[b]{2}{*}{$\mathrm{SA}\left(\mathrm{cm}^{3}\right)$} & \multicolumn{2}{|c|}{ Dunnett's $P$ vs. } & \multirow[b]{2}{*}{ Tips } & \multicolumn{2}{|c|}{ Dunnett's $P$ vs. } \\
\hline & & Control & Aldicarb & & Control & Aldicarb & & Control & Aldicarb \\
\hline Control & 354 & & $\ldots$ & 180 & & $\ldots$ & 424 & & $\ldots$ \\
\hline Aldicarb & 382 & 0.091 & $\ldots$ & 145 & 0.420 & $\ldots$ & 500 & 0.021 & $\ldots$ \\
\hline \multicolumn{10}{|l|}{ B. firmus } \\
\hline $1 \times 10^{6} \mathrm{CFU} /$ seed) & 363 & 0.999 & 0.123 & 181 & 1.000 & 0.517 & 450 & 0.507 & 0.0595 \\
\hline $7 \times 10^{6}$ CFU/seed) & 350 & 0.127 & 0.926 & 146 & 0.527 & 1.000 & 424 & 0.116 & 0.2371 \\
\hline $\left.1.4 \times 10^{7} \mathrm{CFU} / \mathrm{seed}\right)$ & 403 & 0.823 & 0.018 & 185 & 1.000 & 0.114 & 621 & 0.000 & 0.5117 \\
\hline
\end{tabular}

${ }^{\mathrm{a}} \mathrm{L}=$ length, $\mathrm{SA}=$ superficial area, and Tips = number of tips. 
control 30 DAP $(P \leq 0.410)$ (Tables 5 and 6). Additionally, the higher rate increased the number of cotton root tips at 30 DAP $(P \leq$ $0.001)$. However, there were no differences in plant height, shoot dry weight, or root fresh weight between the treatments and the control (Tables 7 and 8).

In the combination greenhouse trial, the combination of the two biologicals at the optimum rates and each biological individually resulted in lower numbers of females $(P \leq 0.001)$ and eggs per gram of root $(P \leq 0.050)$ and vermiform life stages in the soil $(P \leq$ 0.013) 30 DAP compared with the control (Tables 9-11). Additionally, B. firmus and $P$. lilacinus reduced the number of females $(P \leq$ $0.004)$ and eggs when applied individually $(P \leq 0.049)$.

Microplot evaluations. In this trial, the number of vermiform life stages in the soil was reduced by all the biological treatments during the first 60 DAP compared with the control $(P \leq 0.001)$. The reduction of $R$. reniformis populations was similar to that of the aldicarb standard $(P \leq 0.399)$ (Tables $12-14)$. Numbers of females per gram of root were reduced at 30 DAP with $B$. firmus $(P$ $\leq 0.001)$ and $P$. lilacinus $(P \leq 0.039)$ individually and when they were applied together $(P \leq 0.025)$ (Tables 12-14). At the end of the growing season, there were no differences in the number of females in the root among the biological and aldicarb treatments. There was an increase in free-living nematodes at 30 DAP with the combination of the biologicals compared with aldicarb $(P \leq 0.006)$ and the untreated control $(P \leq 0.039)$ (Table 15). Plant parameters were also affected. B. firmus $(P \leq 0.005)$ and $B$. firmus $+P$. lilacinus $(P \leq 0.053)$ influenced plant architecture by supporting larger stem diameters than the control at 60 DAP (Tables 12-14). Also, plants from the combination of $B$. firmus $+P$. lilacinus were taller $(P \leq 0.001)$ when compared with the control. All the treatments, including aldicarb, produced similar cotton seed yields, with a trend toward increasing yields with aldicarb and the combination of $B$. firmus $+P$. lilacinus. However, there were no statistical differences between aldicarb and the biologicals or the control.

Field evaluations. The biologicals $B$. firmus and $P$. lilacinus reduced the number of vermiform life stages of $R$. reniformis in the soil at 90 DAP $(P \leq 0.011)$ (Tables 16-18). The control provided by the biologicals and aldicarb was similar $(P \leq 0.975)$. $P$. lilacinus and aldicarb began reducing vermiform life stages at 60 DAP $(P \leq$ 0.021) (Tables 16-18). The number of females per gram of root was reduced at the end of the season at 150 DAP by the two biologicals combined $(P \leq 0.020)$ and by aldicarb $(P \leq 0.031)$ (data not shown). As observed in the microplots, the $P$. lilacinus treatment increased the number of free-living nematodes 60 DAP $(P \leq 0.007)$ in the field as well. The combination of the biologicals increased free-living nematodes at 60 and 90 DAP, whereas aldicarb treatment reduced the numbers by half (Table 15). The plants in the aldicarb and biological treatments were taller and had increased stem diameter at 90 DAP $(P \leq 0.01)$ as compared with the control (Tables 16-18). At harvest, cotton seed yields were similar between the $B$. firmus and P. lilacinus and aldicarb treatments.

\section{Discussion}

Initial evaluations of $B$. firmus without microflora competition (autoclaved soil) showed that the higher rate of $7 \times 10^{6} \mathrm{CFU} / \mathrm{seed}$ reduced $R$. reniformis females, eggs, and vermiform life stages within the first 30 days of planting. In this test, the insecticide imidacloprid did not show any nematicidal activity. This insecticide is formulated as a seed treatment with B. firmus. The effect of this insecticide was previously evaluated against $M$. ethiopica, and no deleterious effect was observed in nematode reproduction (46).

Table 9. Effect of Paecilomyces lilacinus strain 251 and Bacillus firmus strain GB-126 alone and in combination on plant variables at 30 days after planting under greenhouse conditions $(P \leq 0.05)^{\mathrm{a}}$

\begin{tabular}{|c|c|c|c|c|c|c|c|c|c|}
\hline \multirow[b]{2}{*}{ Treatments } & \multirow[b]{2}{*}{$\mathbf{H}(\mathbf{c m})$} & \multicolumn{2}{|c|}{ Dunnett's $P$ vs. } & \multirow[b]{2}{*}{ ShDW (g) } & \multicolumn{2}{|c|}{ Dunnett's $P$ vs. } & \multirow[b]{2}{*}{ RFW (g) } & \multicolumn{2}{|c|}{ Dunnett's $P$ vs. } \\
\hline & & Control & Aldicarb & & Control & Aldicarb & & Control & Aldicarb \\
\hline Control & 18.0 & & $\cdots$ & 0.9 & & & 2.9 & & $\cdots$ \\
\hline Aldicarb & 18.5 & 0.990 & & 0.85 & 0.992 & $\ldots$ & 2.5 & 0.347 & $\ldots$ \\
\hline B. firmus $\left(1.4 \times 10^{7} \mathrm{CFU} / \mathrm{seed}\right)$ & 17.5 & 0.989 & 0.597 & 0.81 & 0.906 & 0.993 & 3.0 & 1.000 & 0.104 \\
\hline P. lilacinus $(0.3 \% \mathrm{vol} / \mathrm{vol})$ & 17.4 & 0.984 & 0.570 & 0.79 & 0.811 & 0.961 & 3.0 & 1.000 & 0.139 \\
\hline B. firmus $+P$. lilacinus & 17.0 & 0.822 & 0.231 & 0.85 & 0.991 & 1.000 & 3.0 & 1.000 & 0.358 \\
\hline
\end{tabular}

${ }^{\mathrm{a}} \mathrm{H}=$ height, ShDW = shoot dry weight, and RFW = root fresh weight.

Table 10. Effect of Paecilomyces lilacinus strain 251 and Bacillus firmus strain GB-126 alone and in combination on root architecture at 30 days after planting under greenhouse conditions $(P \leq 0.05)^{\mathrm{a}}$

\begin{tabular}{|c|c|c|c|c|c|c|c|c|c|}
\hline \multirow[b]{2}{*}{ Treatments } & \multirow[b]{2}{*}{$\mathbf{L}(\mathbf{c m})$} & \multicolumn{2}{|c|}{ Dunnett's $P$ vs. } & \multirow[b]{2}{*}{ SA (g) } & \multicolumn{2}{|c|}{ Dunnett's $P$ vs. } & \multirow[b]{2}{*}{ Tips } & \multicolumn{2}{|c|}{ Dunnett's $P$ vs. } \\
\hline & & Control & Aldicarb & & Control & Aldicarb & & Control & Aldicarb \\
\hline Control & 440 & & $\ldots$ & 179 & & & 415 & & 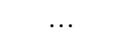 \\
\hline Aldicarb & 381 & 0.891 & $\ldots$ & 166 & 0.982 & $\ldots$ & 417 & 0.982 & \\
\hline B. firmus $\left(1.4 \times 10^{7} \mathrm{CFU} / \mathrm{seed}\right)$ & 500 & 0.897 & 0.269 & 196 & 0.918 & 0.397 & 457 & 0.918 & 0.397 \\
\hline P. lilacinus $(0.3 \% \mathrm{vol} / \mathrm{vol})$ & 407 & 0.989 & 0.996 & 167 & 0.991 & 1.000 & 433 & 0.991 & 1.000 \\
\hline B. firmus $+P$. lilacinus & 413 & 0.995 & 0.985 & 196 & 0.942 & 0.534 & 460 & 0.942 & 0.534 \\
\hline
\end{tabular}

${ }^{\mathrm{a}} \mathrm{L}=$ length, $\mathrm{SA}=$ superficial area, and Tips = number of tips.

Table 11. Effect of Paecilomyces lilacinus strain 251 and Bacillus firmus strain GB-126 alone and in combination on nematodes in the root and soil at 30 days after planting under greenhouse conditions $(P \leq 0.05)^{\mathrm{a}}$

\begin{tabular}{|c|c|c|c|c|c|c|c|c|c|}
\hline \multirow[b]{3}{*}{ Treatments } & \multicolumn{9}{|c|}{ Rotylenchulus reniformis life stages } \\
\hline & \multirow[b]{2}{*}{ Females } & \multicolumn{2}{|c|}{ Dunnett's $P$ vs. } & \multirow[b]{2}{*}{ Eggs } & \multicolumn{2}{|c|}{ Dunnett's $P$ vs. } & \multirow[b]{2}{*}{ Verm } & \multicolumn{2}{|c|}{ Dunnett's $P$ vs. } \\
\hline & & Control & Aldicarb & & Control & Aldicarb & & Control & Aldicarb \\
\hline Control & 86 & & & 1,858 & & & 1,561 & & $\ldots$ \\
\hline Aldicarb & 32 & 0.001 & . & 553 & 0.011 & $\ldots$ & 328 & 0.001 & $\ldots$ \\
\hline B. firmus $\left(1.4 \times 10^{7} \mathrm{CFU} / \mathrm{seed}\right)$ & 63 & 0.004 & 0.001 & 1,011 & 0.119 & 0.140 & 702 & 0.001 & 0.004 \\
\hline P. lilacinus $(0.3 \% \mathrm{vol} / \mathrm{vol})$ & 55 & 0.002 & 0.008 & 837 & 0.049 & 0.383 & 966 & 0.063 & 0.015 \\
\hline B. firmus $+P$. lilacinus & 40 & 0.001 & 0.001 & 848 & 0.050 & 0.312 & 882 & 0.013 & 0.004 \\
\hline
\end{tabular}

${ }^{\text {a }}$ Females and eggs per gram of root, and Verm $=$ vermiforms per $500 \mathrm{~cm}^{3}$ of soil. 
Moreover, imidacloprid has synergistic activity with the entomopathogenic nematodes Sterneinema glaseri and Heterorhabditis bacteriophora against white grubs (30).

In the natural soil microflora competition (nonautoclaved field soil), the higher seed treatment rate $\left(1.4 \times 10^{7} \mathrm{CFU} / \mathrm{seed}\right)$ of $B$. firmus had $37 \%$ fewer vermiform life stages and $21 \%$ fewer eggs of $R$. reniformis compared with the untreated seed control. Similar results of this strain were previously reported for $M$. incognita on tomato under greenhouse conditions (47). Eight grams of the wettable powder formulation of $B$. firmus was applied to tomato seedlings planted in $1,200 \mathrm{~cm}^{3}$ of sterilized soil. The final $M$. incognita population was reduced by $76 \%$ and the number of eggs of $M$. incognita by $45 \%$ (47). Furthermore, the application of the wettable powder formulation of B. firmus at rates of 1.8 and 3.6 $\mathrm{g} / \mathrm{kg}$ of soil to cucumber plants reduced eggs hatched of a Meloidogyne spp. (15). In these trials, a wettable powder formulation was used, and the main action against the nematodes was unclear for the authors. They suggest a major contribution of

Table 12. Effect of Paecilomyces lilacinus strain 251 and Bacillus firmus strain GB-126 alone and in combination on plant height (H) under microplot conditions $(P \leq 0.05)^{\mathrm{a}}$

\begin{tabular}{|c|c|c|c|c|c|c|c|c|c|}
\hline \multirow[b]{3}{*}{ Treatments } & \multicolumn{3}{|c|}{30 DAP } & \multicolumn{3}{|c|}{60 DAP } & \multicolumn{3}{|c|}{90 DAP } \\
\hline & \multirow[b]{2}{*}{$\mathbf{H}(\mathbf{c m})$} & \multicolumn{2}{|c|}{ Dunnett's $P$ vs. } & \multirow[b]{2}{*}{$\mathbf{H}(\mathbf{c m})$} & \multicolumn{2}{|c|}{ Dunnett's $P$ vs. } & \multirow[b]{2}{*}{$\mathbf{H}(\mathbf{c m})$} & \multicolumn{2}{|c|}{ Dunnett's $P$ vs. } \\
\hline & & Control & Aldicarb & & Control & Aldicarb & & Control & Aldicarb \\
\hline Control & 19.0 & & & 36.8 & & & 44.8 & & \\
\hline Aldicarb & 19.4 & 0.791 & $\ldots$ & 38.4 & 0.297 & $\ldots$ & 45.9 & 0.422 & $\ldots$ \\
\hline B. firmus $\left(1.4 \times 10^{7} \mathrm{CFU} / \mathrm{seed}\right)$ & 18.1 & 0.633 & 0.466 & 38.9 & 0.260 & 0.795 & 43.4 & 0.422 & 0.218 \\
\hline P. lilacinus $(0.3 \% \mathrm{vol} / \mathrm{vol})$ & 20.1 & 0.550 & 0.707 & 39.5 & 0.046 & 0.444 & 45.8 & 0.474 & 0.920 \\
\hline B. firmus $+P$. lilacinus & 19.4 & 0.805 & 0.989 & 42.2 & 0.001 & 0.013 & 47.7 & 0.085 & 0.366 \\
\hline
\end{tabular}

${ }^{\mathrm{a}} \mathrm{DAP}=$ days after planting.

Table 13. Effect of Paecilomyces lilacinus strain 251 and Bacillus firmus strain GB-126 alone and in combination on stem diameter (SD) under microplot conditions $(P \leq 0.05)^{\mathrm{a}}$

\begin{tabular}{|c|c|c|c|c|c|c|c|c|c|}
\hline \multirow[b]{3}{*}{ Treatments } & \multicolumn{3}{|c|}{30 DAP } & \multicolumn{3}{|c|}{60 DAP } & \multicolumn{3}{|c|}{90 DAP } \\
\hline & \multirow[b]{2}{*}{ SD $(\mathbf{c m})$} & \multicolumn{2}{|c|}{ Dunnett's $P$ vs. } & \multirow[b]{2}{*}{ SD $(\mathbf{c m})$} & \multicolumn{2}{|c|}{ Dunnett's $P$ vs. } & \multirow[b]{2}{*}{ SD $(\mathbf{c m})$} & \multicolumn{2}{|c|}{ Dunnett's $P$ vs. } \\
\hline & & Control & Aldicarb & & Control & Aldicarb & & Control & Aldicarb \\
\hline Control & 3.6 & & $\cdots$ & 6.6 & & & 6.9 & & \\
\hline Aldicarb & 3.7 & 0.998 & .. & 7.1 & 0.793 & & 7 & 1.000 & \\
\hline B. firmus $\left(1.4 \times 10^{7} \mathrm{CFU} / \mathrm{seed}\right)$ & 3.6 & 1.000 & 0.996 & 8.2 & 0.005 & 0.02 & 8.2 & 0.021 & 0.008 \\
\hline P. lilacinus $(0.3 \% \mathrm{vol} / \mathrm{vol})$ & 3.8 & 0.984 & 0.999 & 7.2 & 0.764 & 1.00 & 7.6 & 0.702 & 0.698 \\
\hline B. firmus $+P$. lilacinus & 3.7 & 0.993 & 1.000 & 7.8 & 0.053 & 0.24 & 7.6 & 0.603 & 0.567 \\
\hline
\end{tabular}

${ }^{\mathrm{a}} \mathrm{DAP}=$ days after planting.

Table 14. Effect of Paecilomyces lilacinus strain 251 and Bacillus firmus strain GB-126 alone and in combination on Rotylenchulus reniformis vermiform stage in soil under microplot conditions $(P \leq 0.05)^{\mathrm{a}}$

\begin{tabular}{|c|c|c|c|c|c|c|c|c|c|}
\hline \multirow[b]{3}{*}{ Treatments } & \multicolumn{3}{|c|}{30 DAP } & \multicolumn{3}{|c|}{60 DAP } & \multicolumn{3}{|c|}{90 DAP } \\
\hline & \multirow[b]{2}{*}{ Verm } & \multicolumn{2}{|c|}{ Dunnett's $P$ vs. } & \multirow[b]{2}{*}{ Verm } & \multicolumn{2}{|c|}{ Dunnett's $P$ vs. } & \multirow[b]{2}{*}{ Verm } & \multicolumn{2}{|c|}{ Dunnett's $P$ vs. } \\
\hline & & Control & Aldicarb & & Control & Aldicarb & & Control & Aldicarb \\
\hline Control & 122 & & $\ldots$ & 597 & & & 1,037 & & $\ldots$ \\
\hline Aldicarb & 60 & 0.001 & $\cdots$ & 197 & 0.001 & $\ldots$ & 502 & 0.020 & $\ldots$ \\
\hline B. firmus $\left(1.4 \times 10^{7} \mathrm{CFU} / \mathrm{seed}\right)$ & 51 & 0.001 & 0.561 & 259 & 0.001 & 0.386 & 964 & 0.455 & 0.187 \\
\hline P. lilacinus $(0.3 \% \mathrm{vol} / \mathrm{vol})$ & 84 & 0.039 & 0.030 & 232 & 0.001 & 0.280 & 621 & 0.059 & 0.442 \\
\hline B. firmus $+P$. lilacinus & 78 & 0.025 & 0.512 & 211 & 0.001 & 0.399 & 578 & 0.071 & 0.277 \\
\hline
\end{tabular}

a DAP $=$ days after planting and Verm $=$ vermiform life stages per $150 \mathrm{~cm}^{3}$ of soil.

Table 15. Effect of Paecilomyces lilacinus strain 251 and Bacillus firmus strain GB-126 alone and in combination on free-living nematodes in soil under microplot and field conditions $(P \leq 0.05)^{\mathrm{a}}$

\begin{tabular}{|c|c|c|c|c|c|c|c|c|c|}
\hline \multirow[b]{3}{*}{ Treatments } & \multicolumn{3}{|c|}{30 DAP } & \multicolumn{3}{|c|}{60 DAP } & \multicolumn{3}{|c|}{90 DAP } \\
\hline & \multirow[b]{2}{*}{ FL } & \multicolumn{2}{|c|}{ Dunnett's $P$ vs. } & \multirow[b]{2}{*}{ FL } & \multicolumn{2}{|c|}{ Dunnett's $P$ vs. } & \multirow[b]{2}{*}{ FL } & \multicolumn{2}{|c|}{ Dunnett's $P$ vs. } \\
\hline & & Control & Aldicarb & & Control & Aldicarb & & Control & Aldicarb \\
\hline \multicolumn{10}{|l|}{ Microplot } \\
\hline Control & 22 & & $\ldots$ & 30 & & $\ldots$ & 27 & & $\ldots$ \\
\hline Aldicarb & 6 & 0.116 & $\ldots$ & 14 & 0.319 & $\ldots$ & 11 & 0.002 & . \\
\hline B. firmus $\left(1.4 \times 10^{7} \mathrm{CFU} / \mathrm{seed}\right)$ & 22 & 0.640 & 0.119 & 19 & 0.590 & 0.669 & 73 & 0.250 & 0.002 \\
\hline P. lilacinus $(0.3 \% \mathrm{vol} / \mathrm{vol})$ & 32 & 0.251 & 0.091 & 16 & 0.840 & 0.514 & 16 & 1.000 & 0.319 \\
\hline B. firmus $+P$. lilacinus & 41 & 0.039 & 0.006 & 32 & 0.416 & 0.114 & 43 & 0.327 & 0.001 \\
\hline \multicolumn{10}{|l|}{ Field } \\
\hline Control & 59 & & $\ldots$ & 27 & & $\ldots$ & 32 & & $\ldots$ \\
\hline Aldicarb & 119 & 0.033 & $\ldots$ & 35 & 0.366 & $\ldots$ & 57 & 0.63 & $\ldots$ \\
\hline B. firmus $\left(1.4 \times 10^{7} \mathrm{CFU} / \mathrm{seed}\right)$ & 81 & 0.343 & 0.011 & 62 & 0.049 & 0.278 & 100 & 0.011 & 0.072 \\
\hline P. lilacinus $(0.3 \% \mathrm{vol} / \mathrm{vol})$ & 111 & 0.759 & 0.260 & 70 & 0.007 & 0.066 & 86 & 0.008 & 0.054 \\
\hline B. firmus $+P$. lilacinus & 138 & 0.105 & 0.789 & 51 & 0.080 & 0.352 & 130 & 0.001 & 0.013 \\
\hline
\end{tabular}

${ }^{\mathrm{a}} \mathrm{DAP}=$ days after planting and $\mathrm{FL}=$ free-living nematodes per $150 \mathrm{~cm}^{3}$ of soil. 
the additives of the formulation and that B. firmus plays an additional role in nematode control. However, in vitro studies demonstrate that the production of bioactive secondary compounds by this bacterium were deleterious to Radopholus similis, $M$. incognita, and D. dipsaci and inhibited hatching of $M$. incognita eggs (34). Studies on seed treatments with abamectin report suppression of penetration and infection of $M$. incognita and Rotylenchulus reniformis on cotton at a root length of $5 \mathrm{~cm}$ in vitro but protection decreases as the taproot length increases (12). In the case of seed treatments with B. firmus, it is possible that the protection lasts longer due to the multiplication of the live bacteria with the cotton root as it grows in length. Cotton plants treated with higher seed-treatment rates of $B$. firmus produced more root tips than the untreated control and had a longer root length than the aldicarb treatment. Increases of root tips can represent higher uptake of nutrients and water from the soil. Studies in tomato also showed an increase of 50\% in plant biomass and a $91 \%$ reduction of the gall formations in the root by M. incognita (47).

In autoclaved soil, P. lilacinus at a rate of $0.2 \%(\mathrm{vol} / \mathrm{vol})$ delayed the infection of $R$. reniformis and reduced vermiform life stages and eggs during the first 30 days. As a result of this protection, root fresh weight was higher than the untreated control and aldicarb treatment. Previous trials using a different strain of $P$. lilacinus on cotton plants under greenhouse conditions showed a reduction of $R$. reniformis eggs in autoclaved soil but not in nonautoclaved soil at a rate of $0.1 \%(\mathrm{vol} / \mathrm{vol})(9)$. In contrast, P. lilacinus strain 251 reduced females, eggs, and vermiform life stages at 0.2 and $0.3 \%$
( vol/vol) in nematode-infested field soil. This coincides with earlier greenhouse studies where $R$. reniformis eggs and vermiform life stages were reduced in tomato plants by $41 \%$ when $P$. lilacinus was applied at a rate of $5 \mathrm{~g}$ of colonized rice (48) and $51 \%$ at a rate of $2 \mathrm{~g}$ per plant after 60 days (39). In castor plants (Ricinus communis L.) and basil (Ocimum basilicum L.), reduction of this nematode was observed after 100 days using $8 \mathrm{~g}$ of $P$. lilacinus inoculum on a rice seed carrier (1). Moreover, this fungus has been reported to reduce root galling caused by $M$. incognita on tomato plants by $36 \%$ with the application of $20 \mathrm{~g}$ of fungus-infested wheat seed 10 days after transplanting (7). P. lilacinus is an aggressive egg-parasite fungus that can be implemented in Rotylenchulus reniformis management programs. Eggs of $R$. reniformis are laid outside the cotton root, and second-stage juveniles usually hatch within 7 days. These characteristics of $R$. reniformis reproduction probably enhance their susceptibility to parasitism by $P$. lilacinus This fungus invades the eggs within $48 \mathrm{~h}$ under in vitro conditions (9). Biocontrol provided by P. lilacinus was different than the control achieved with aldicarb. Aldicarb reduced all the nematodes in the soil, including the free-living nematodes. In contrast, freeliving nematodes were higher in all $P$. lilacinus rates evaluated. Comparable outcomes were observed with free-living nematode responses to fenamifos and $P$. lilacinus, where the chemical nematicides reduced all nematodes while $P$. lilacinus increased free-living populations on carnation (31). This fungus colonizes the epidermis of the roots (7), which may explain the protection and increase in root fresh weight, root surface area, and number of tips at the rate of $0.3 \%$ (vol/vol).

Table 16. Effect of Paecilomyces lilacinus strain 251 and Bacillus firmus strain GB-126 alone and in combination on plant height (H) under field conditions $(P \leq 0.05)^{\mathrm{a}}$

\begin{tabular}{|c|c|c|c|c|c|c|c|c|c|}
\hline \multirow[b]{3}{*}{ Treatments } & \multicolumn{3}{|c|}{30 DAP } & \multicolumn{3}{|c|}{60 DAP } & \multicolumn{3}{|c|}{90 DAP } \\
\hline & \multirow[b]{2}{*}{$\mathbf{H}(\mathbf{c m})$} & \multicolumn{2}{|c|}{ Dunnett's $P$ vs. } & \multirow[b]{2}{*}{$\mathbf{H}(\mathbf{c m})$} & \multicolumn{2}{|c|}{ Dunnett's $P$ vs. } & \multirow[b]{2}{*}{$\mathbf{H}(\mathbf{c m})$} & \multicolumn{2}{|c|}{ Dunnett's $P$ vs. } \\
\hline & & Control & Aldicarb & & Control & Aldicarb & & Control & Aldicarb \\
\hline Control & 14.9 & & . & 52.5 & & & 80.8 & & . \\
\hline Aldicarb & 16.8 & 0.022 & 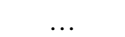 & 60.2 & 0.113 & & 91.2 & 0.013 & \\
\hline B. firmus $\left(1.4 \times 10^{7} \mathrm{CFU} / \mathrm{seed}\right)$ & 15.4 & 0.571 & 0.041 & 54.5 & 0.642 & 0.241 & 86.1 & 0.236 & 0.265 \\
\hline P. lilacinus $(0.3 \% \mathrm{vol} / \mathrm{vol})$ & 15.7 & 0.282 & 0.109 & 58.5 & 0.155 & 0.719 & 90.8 & 0.027 & 0.925 \\
\hline B. firmus $+P$. lilacinus & 15.8 & 0.291 & 0.251 & 58.7 & 0.162 & 0.761 & 91.3 & 0.007 & 0.980 \\
\hline
\end{tabular}

a DAP $=$ days after planting.

Table 17. Effect of Paecilomyces lilacinus strain 251 and Bacillus firmus strain GB-126 alone and in combination on stem diameter (SD) under field conditions $(P \leq 0.05)^{\mathrm{a}}$

\begin{tabular}{|c|c|c|c|c|c|c|c|c|c|}
\hline \multirow[b]{3}{*}{ Treatments } & \multicolumn{3}{|c|}{30 DAP } & \multicolumn{3}{|c|}{60 DAP } & \multicolumn{3}{|c|}{90 DAP } \\
\hline & \multirow[b]{2}{*}{ SD $(\mathbf{c m})$} & \multicolumn{2}{|c|}{ Dunnett's $P$ vs. } & \multirow[b]{2}{*}{ SD $(\mathbf{c m})$} & \multicolumn{2}{|c|}{ Dunnett's $P$ vs. } & \multirow[b]{2}{*}{ SD $(\mathbf{c m})$} & \multicolumn{2}{|c|}{ Dunnett's $P$ vs. } \\
\hline & & Control & Aldicarb & & Control & Aldicarb & & Control & Aldicarb \\
\hline Control & 3.7 & & $\ldots$ & 8.0 & & $\ldots$ & 10.7 & & $\ldots$ \\
\hline Aldicarb & 4.2 & 0.021 & $\ldots$ & 9.2 & 0.030 & $\ldots$ & 12.7 & 0.001 & $\ldots$ \\
\hline B. firmus $\left(1.4 \times 10^{7} \mathrm{CFU} / \mathrm{seed}\right)$ & 3.9 & 0.396 & 0.082 & 8.4 & 0.388 & 0.181 & 12.1 & 0.016 & 0.342 \\
\hline P. lilacinus $(0.3 \% \mathrm{vol} / \mathrm{vol})$ & 4.1 & 0.048 & 0.496 & 8.8 & 0.102 & 0.519 & 12.1 & 0.014 & 0.323 \\
\hline B. firmus $+P$. lilacinus & 3.9 & 0.633 & 0.155 & 9.3 & 0.013 & 0.896 & 12.4 & 0.006 & 0.371 \\
\hline
\end{tabular}

${ }^{a} \mathrm{DAP}=$ days after planting.

Table 18. Effect of Paecilomyces lilacinus strain 251 and Bacillus firmus strain GB-126 alone and in combination on Rotylenchulus reniformis vermiform stage in soil under field conditions $(P \leq 0.05)^{\mathrm{a}}$

\begin{tabular}{|c|c|c|c|c|c|c|c|c|c|}
\hline \multirow[b]{3}{*}{ Treatments } & \multicolumn{3}{|c|}{30 DAP } & \multicolumn{3}{|c|}{60 DAP } & \multicolumn{3}{|c|}{90 DAP } \\
\hline & \multirow[b]{2}{*}{ Verm } & \multicolumn{2}{|c|}{ Dunnett's $P$ vs. } & \multirow[b]{2}{*}{ Verm } & \multicolumn{2}{|c|}{ Dunnett's $P$ vs. } & \multirow[b]{2}{*}{ Verm } & \multicolumn{2}{|c|}{ Dunnett's $P$ vs. } \\
\hline & & Control & Aldicarb & & Control & Aldicarb & & Control & Aldicarb \\
\hline Control & 1,458 & & & 586 & & & 2,651 & & 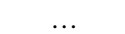 \\
\hline Aldicarb & 1,102 & 0.214 & & 289 & 0.002 & & 2,066 & 0.087 & \\
\hline B. firmus $\left(1.4 \times 10^{7} \mathrm{CFU} / \mathrm{seed}\right)$ & 1,094 & 0.398 & 0.540 & 424 & 0.151 & 0.122 & 1,906 & 0.001 & 0.948 \\
\hline P. lilacinus $(0.3 \% \mathrm{vol} / \mathrm{vol})$ & 1,269 & 0.737 & 0.308 & 348 & 0.021 & 0.496 & 1,882 & 0.009 & 0.826 \\
\hline B. firmus $+P$. lilacinus & 1,202 & 0.804 & 0.238 & 443 & 0.221 & 0.082 & 1,933 & 0.011 & 0.975 \\
\hline
\end{tabular}

${ }^{\text {a }}$ DAP $=$ days after planting and Verm $=$ vermiform life stages per $150 \mathrm{~cm}^{3}$ of soil. 
In vitro observations of $B$. firmus and $P$. lilacinus being cultured in petri dishes did not show any antagonism between this bacterium and fungus. Previous studies indicated no incompatibility between $P$. lilacinus and B. firmus under in vitro conditions (35). The combination of $B$. firmus and $P$. lilacinus under greenhouse conditions improved the biocontrol of $R$. reniformis in the root compared with their individual applications. Similar results were reported when biocontrol of Radopholus similis was increased with the application of $F$. oxysporum with $B$. firmus and $P$. lilacinus in banana plants (35). Furthermore, combination of $P$. lilacinus with Monacrosporium lysipagum reduced populations of $M$. javanica, $R$. similis, and Heterodera avenae in tomato, banana, and barley plants, respectively (25). These trials indicate that the combination of biocontrol agents with different actions provides enhanced control over a single agent.

Previous studies have reported reductions of plant-parasitic nematodes and increased yields under field conditions. B. firmus reduced Meloidogyne spp. on Hypericum plants with a single preplant application through the irrigation system, and protection lasted for 3 months (4). Additionally, B. firmus suppressed Meloidogyne spp. on cucumber plants from 60 DAP until the end of the season (16) and, when it was combined with soil solarization, reduction of nematodes was similar to the soil fumigant dazomet (15). Furthermore, P. lilacinus reduced M. incognita on Piper betle L. with three field applications (24). Under microplot and field conditions, reduction of Rotylenchulus reniformis was consistent with greenhouse trials when the two biocontrol agents were applied together. Reductions of nematode population occurred from when cotton plants started blooming (60 DAP) until full blooming (90 DAP). At this time, stem diameter, plant height, and free-living nematodes' populations also increased. Combinations of the two biocontrol agents resulted in a seed cotton yield comparable with chemical nematicide.

In summary, the two commercial biocontrol products consistently reduced vermiform life stages and numbers of females in the roots in all the environments tested. The level of control provided by the combination of the two biologicals was statistically the same as the control from aldicarb. This suggests that combining antagonists that attack different life stages of $R$. reniformis provides a more effective control with multiple pathogenicity actions than using only one biocontrol agent. Paecilomyces lilacinus reduced females and eggs while $B$. firmus affected the vermiform life stages. Similar results were obtained in the reduction of Radopholus similis on banana plants, where the application of these two biologicals with the endophytic $F$. oxysporum strain 162 reduced nematode damage in the roots (35). Additionally, the combination of these biologicals increased free-living nematodes, which play an important role in nutrient cycling in soil ecosystems and are often used as biological indicators of soil health $(13,37)$. The orders of free-living nematodes that increased in the combined biological treatment were Rhabditida and Mononchida. The first one is a bacterial feeder and the second one is reported as an omnivore. Mononchida, in their initial stages, could be bacterial feeders and, in later stages, predators of protozoa or nematodes (51). These nematodes, depending on their biology or feeding habit, have many beneficial aspects and can help to spread fungi or bacteria in the soil in their cuticles or by the passage of bacteria or fungi through their intestines. Studies on wheat seed treated with Pseudomonas fluorescens SBW25 showed an increase in root colonization when free-living nematodes were present (29). Horiuchi et al. (19) reported that Caenorhabditis elegans spreads Sinorhizobium meliloti to legume roots in response to plant-released volatiles that attract the nematode. Recent publications indicate that these nematodes are potential antagonists of plant-parasitic nematodes (3).

Understanding the interaction of free-living nematodes with $B$. firmus and Paecilomyces lilacinus can enhance the reduction of Rotylenchulus reniformis. Research is needed to determine whether free-living nematodes decrease $R$. reniformis by predation or whether they enhance efficacy of the biocontrol agents by spreading them through the soil. Enhancing spread through soil would be an advantage because $R$. reniformis colonizes roots up to $90 \mathrm{~cm}$ deep in silty clay loam soils (36). Future experiments need to determine whether there is an accumulative biocontrol effect in the soil after continuous applications of the biocontrol agents.

\section{Acknowledgments}

This work was supported, in part, by the Alabama Cotton Commission and Cotton Inc. The authors thank William D. Fowler for assistance in editing the manuscript.

\section{Literature Cited}

1. Ahmad, A., and Alam, M. M. 1998. Effect of organic amendments alone and in combination with Paecilomyces lilacinus on Rotylenchulus reniformis attacking some economically important crop plants. Arch. Phytopathol. Pflanzenschutz 31:439-448.

2. Bayer. 2010. Revised Temik 15G label overview August 16, 2010. Bayer CropScience. http://iaspub.epa.gov/apex/pesticides/f?p=PPLS:102:::NO:: P102_REG_NUM:264-330

3. Bilgrami, A. L., and Brey, C. 2008. Potential of predatory nematodes to control plant-parasitic nematodes. Pages 447-461 in: Nematodes as Biocontrol Agents. P. S. Grewal, R. U. Ehlers, and D. I. Shapiro-Ilan, eds. CABI, Wallingford, UK.

4. Blachinsky, D., Antonov, J., Bercovitz, A., El-ad, B., Feldman, K., Husid, A., Lazare, M., Marcov, N., Shamai, I., and Keren-Zur, M. 2007. BioNem WP: A unique tool for nematode control. www.oocities.org/tesfish_ 2000/FinalThesis.doc

5. Blasingame, D., Patel, M. V., Lawrence, K., Gazaway, W., Olsen, M., Kirkpatrick, T., Monfort, S., Davis, M., Marios, J., Kemerait, B., Colyer, P., Scuimbato, G., Lawrence, G., Wrather, A., Goldberg, N., Koenning, S. Pitts, J. T., Muller, J., Newman, M., Woodward, J., Wheeler, T., and Phipps, P. 2010. 2009 Disease loss estimate committee report. Proc. Beltwide Cotton Conf., Vol. 1:238-240. National Cotton Council of America, Memphis, TN.

6. Bonants, P. J. M., Fitters, P. L. F., Thijs, H., Den Belder, E., Waalwijk, C., and Henfling, D. M. 1995. A basic serine protease from Paecilomyces lilacinus with biological activity against Meloidogyne hapla eggs. Microbiology 141:775-784.

7. Cabanillas, E., Barker, K. R., and Daykin, M. E. 1988. Histology of the interactions of Paecilomyces lilacinus with Meloidogyne incognita on tomato. J. Nematol. 20:362-365.

8. Castillo, J. D., and Lawrence, K. S. 2011. First report of Catenaria auxiliaris parasitizing the reniform nematode Rotylenchulus reniformis on cotton in Alabama. Plant Dis. 95:490.

9. Castillo, J. D., Lawrence, K. S., Kloepper, J. W., and van Santen, E. 2010. Evaluation of Drechslerella dactyloides, Drechslerella brochopaga, and Paecilomyces lilacinus for the biocontrol of Rotylenchulus reniformis. Nematropica 40:71-85

10. Castillo, J. D., Lawrence, K. S., Morgan-Jones, G., and Ramirez, C. A. 2010. Identification of fungi associated with Rotylenchulus reniformis. J. Nematol. 42:313-138.

11. Dackman, C., and Nordbring-Hertz, B. 1985. Fungal parasites of the cereal cyst nematode Heterodera avenae in southern Sweden. J. Nematol. 17:5055 .

12. Faske, T. R., and Starr, J. L. 2007. Cotton root protection from plant-parasitic nematodes by Abamectin-treated seed. J. Nematol. 39:27-30.

13. Ferris, H., and Bongers, T. 2006. Nematode indicators of organic enrichment. J. Nematol. 38:3-12.

14. Freitas, L. G., Ferraz, S., and Muchovej, J. J. 1995. Effectiveness of different isolates of Paecilomyces lilacinus and isolate of Cylindrocarpon de structans on the control of Meloidogyne javanica. Nematropica 25:109-115.

15. Giannakou, O. I., Anastasiadis, A. I., Gowen, S. R, and Prophetou-Athanasiadou, D. A. 2007. Effects of a non-chemical nematicide combined with soil solarization for the control of root-knot nematodes. Crop Prot. 26:16441654.

16. Giannakou, O. I., Karpouzas, D. G., and Prophetou-Athanasiadou, D. A. 2004. A novel non-chemical nematicide for the control of root-knot nematodes. Appl. Soil Ecol. 26:69-79.

17. Hewlett, T. E., Stetina, S. R., Schmidt, L. M., Waters, J. P., Simmons, L. J. and Rich, J. R. 2009. Identification of Pasteuria spp. that parasitize Rotylenchulus reniformis. (Abstr.) J. Nematol. 41:338.

18. Hooper, D. J. 1986. Preserving and staining nematodes in plant tissues. Page 81 in: Laboratory Methods for Work with Plant and Soil Nematodes. J. F. Southey, ed. Ministry of Agriculture, Fisheries and Food, London.

19. Horiuchi, J., Prithiviraj, B., Bais, H. B., Kimball, B. A., and Vivanco, J. M 2005. Soil nematodes mediate positive interactions between legume plants and rhizobium bacteria. Planta 222:848-857.

20. Hussey, R. S., and Barker, K. R. 1973. A comparison of methods of collecting inocula for Meloidogyne spp. including a new technique. Plant Dis. Rep. 57:1025-1028.

21. Jatala, P., Kaltenbach, R., and Bocangel, M. 1979. Biological control of Meloidogyne incognita and Globodera pallida on potatoes. (Abstr.) J. Nematol. 11:303. 
22. Jayakumar, J., Ramakrishnan, S., and Rajendran, G. 2003. Bio-efficacy of fluorescent Pseudomonads isolates against reniform nematode, Rotylenchulus reniformis infecting cotton. Indian J. Nematol. 33:13-15.

23. Jenkins, W. R. 1964. A rapid centrifugal-flotation technique for separating nematodes from soil. Plant Dis. Rep. 48:692.

24. Jonathan, E. I., Arulmozhiyan, R., Muthusamy, S., and Manuel, W. W. 2000. Field application of Paecilomyces lilacinus for the control of Meloidogyne incognita on betelvine, Piper betle. Nematol. Mediterr. 28:131-133.

25. Khan, A., Williams, K. L., and Nevalainen, H. K. M. 2006. Control of plantparasitic nematodes by Paecilomyces lilacinus and Monacrosporium lysipagum in pot trials. Biocontrol 51:643-658.

26. Kiewnick, S. 2009. Importance of multitrophic interactions for successful biocontrol of plant parasitic nematodes with Paecilomyces lilacinus strain 251. Pages 81-92 in: Recent Developments in Management of Plant Diseases. U. Gisi, I. Chet, and M. L. Gullino, eds. Springerlink. New York.

27. Kiewnick, S., and Sikora, R. A. 2006. Biological control of the root-knot nematode Meloidogyne incognita by Paecilomyces lilacinus strain 251. Biol. Control 38:179-187.

28. Kim, D. G., and Riggs, R. D. 1994. Techniques for isolation and evaluation of fungal parasites of Heterodera glycines. J. Nematol. 26:592-595.

29. Knox, O. G., Killham, K., Artz, R. R. E., Mullins, C., and Wilson, M. 2004. Effect of nematodes on rhizosphere colonization by seed-applied bacteria. Appl. Environ. Microbiol. 70:4666-4671.

30. Koppenhöfer, A. M., Grewal, P. S., and Kaya, H. K., 2000. Synergism of imidacloprid and entomopathogenic nematodes against white grubs: the mechanism. Entomol. Exp. Appl. 94:283-293.

31. Langat, J. K., Kimenju, J. W., Mutua, G. K., Muiru, W. M., and Otieno, W. 2008. Response of free-living nematodes to treatments targeting plant parasitic nematodes in carnation. Asian J. Plant Sci. 7:467-472.

32. Lopez-Llorca, L. V., Maciá-Vicente, J. G., and Jansson, H. B. 2008. Mode of action and interactions of nematophagous fungi. Pages 51-76 in: Integrated Management and Biocontrol of Vegetable and Grain Crops Nematodes. A. Ciancio and K. G. Mukerji, eds. Springerlink, New York.

33. McLean, K. S., Palmateer, A. J., and Morgan-Jones, G. 2000. Fungal antagonists of Rotylenchulus reniformis. In: Proc. Belt. Conf. Natl. Cotton Counc. Am. 1:145-146.

34. Mendoza, A. R., Kiewnick, S., and Sikora, R. 2008. In vitro activity of Bacillus firmus against the burrowing nematode Radopholus similis, the root-knot nematode Meloidogyne incognita, and the stem nematode Ditylenchus dipsaci. Biocontrol Sci. Technol. 18:377-389.

35. Mendoza, A. R., and Sikora, R. 2009. Biological control of Radopholus similis in banana by combined application of the mutualistic endophyte Fusarium oxysporum strain 162, the egg pathogen Paecilomyces lilacinus strain 251 and the antagonistic bacteria Bacillus firmus. Biocontrol 54:263273.

36. Moore, S. R., Lawrence, K. S., Arriaga, F. J., van Santen, E., and Burmester,
C. 2008. Dimensional movement of Rotylenchulus reniformis through a Decatur Silt loam soil under variable soil moistures. Proc. Belt. Conf. Natl Cotton Counc. Am. 1:221-226.

37. Neher, D. A. 2010. Ecology of plant and free-living nematodes in natural and agricultural soil. Annu. Rev. Phytopathol. 48:371-394.

38. Park, J. O., Hargreaves, J. R., McConville, E. J., Stirling, G. R., Ghisalberti, E. L., and Sivasithamparam, K. 2004. Production of leucinostatins and nematicidal activity of Australian isolates of Paecillomyces lilacinus (Thom) Samson. Lett. Appl. Microbiol. 38:271-276.

39. Reddy, P., and Khan, R. M. 1988. Evaluation of Paecilomyces lilacinus for the biological control of Rotylenchulus reniformis infecting tomato, compared with carbofuran. Nematol. Mediterr. 16:113-115.

40. Robinson, A. F. 2007. Reniform in U.S. cotton: when, where, why, and some remedies. Annu. Rev. Phytopathol. 45:263-288.

41. Robinson, A. F. 2008. Nematode management in cotton. Pages 149-182 in: Integrated Management and Biocontrol of Vegetable and Grain Crops Nematodes. A. Ciancio and K. G. Mukerji, eds. Springerlink, New York.

42. Robinson, A. F., Westphal, A., Overstreet, C., Padgett, G. B., Greenberg, S M., Wheeler, T. A., and Stetina S. R. 2008. Detection of suppressivenes against Rotylenchulus reniformis in soil from cotton (Gossypium hirsutum) fields in Texas and Louisiana. J. Nematol. 40:35-38.

43. Schmidt, L. M., Hewlett, T. E., Green, A., Simmons, L. J., Kelley, K., Doroh, M., and Stetina, S. R. 2010. Molecular and morphological characterization and biological control capabilities of a Pasteuria spp. parasitizing Rotylenchulus reniformis, the reniform nematode. J. Nematol. 42:207-217.

44. Schrimsher, D. W., Lawrence, K. S., Castillo, J. D., Moore, S. R., and Kloepper, J. W. 2011. Effects of Bacillus firmus GB-126 on the soybean cyst nematode mobility in vitro. (Abstr.) Phytopathology 101:S161.

45. Stirling, G. R. 1991. Biological Control of Plant Parasitic Nematodes. CABI, Wallingford, UK.

46. Strajnar, P., and Sirca, S. 2011. The effect of some nematicides, natura compounds and tomato cv. Venezia with Mi gene on the nematode Meloido gyne ethiopica (Nematoda) reproduction. Acta Agric. Sloven. 97:5-10.

47. Terefe, M., Tefera, T., and Sakhuja, P. K. 2009. Effect of a formulation of Bacillus firmus on root-knot nematode Meloidogyne incognita infestation and the growth of tomato plants in the greenhouse and nursery. J. Invertebr. Pathol. 100:94-99.

48. Walters, S. A., and Barker, K. R. 1994. Efficacy of Paecilomyces lilacinus in suppressing Rotylenchulus reniformis on tomato. J. Nematol. 26:600-605.

49. Wang, K., Riggs, R. D., and Crippen, D. 2004. Suppression of Rotylenchulus reniformis on cotton by the nematophagous fungus ARF. J. Nematol. 36:186-191.

50. Wang, K., Riggs, R. D., and Crippen, D. 2005. Isolation, selection, and efficacy of Pochonia chlamydosporia for control of Rotylenchulus reniformis on cotton. Phytopathology 95:890-893.

51. Yates, G. 1987. Nematode feeding and activity: The importance of development stages. Biol. Fertil. Soils 3:143-146. 